Article

\title{
Beyond Gender: Reflections on a Contemporary Case of Double Monastery in Orthodox Monasticism-St. John the Baptist Monastery of Essex in England
}

\author{
Maria Chiara Giorda ${ }^{1, *}$ and Ioan Cozma ${ }^{2}(\mathbb{C}$ \\ 1 Department of Humanities, Roma Tre University, 234 Via Ostiense, 00146 Rome, Italy \\ 2 Faculty of Eastern Canon Law, Pontifical Oriental Institute, 7 Piazza di S. Maria Maggiore, 00185 Rome, Italy \\ * Correspondence: mariachiara.giorda@uniroma3.it
}

Received: 18 June 2019; Accepted: 21 July 2019; Published: 26 July 2019

\begin{abstract}
This paper focuses on the contemporary controversy in the Orthodox Church regarding the non-existence of the monasteries, where monks and nuns cohabit (so-called "double-monasteries"), which were prohibited by the Byzantine legislation and the Seventh Ecumenical Council (Nicea 787). The article attempts to demonstrate that, in spite of the centuries-old prohibition, the Orthodox Monastery of St. John the Baptist is an exceptional contemporary case of such cohabitation: monks and nuns live under the roof of the same monastery, sharing common places and certain activities. Furthermore, the paper envisions a possible accommodation in the monastic vision and practice regarding gender cohabitation in Orthodox monasticism. The research employs the historical-critical method, which is based on literary, archeological, and documentary sources, as well as interviews.
\end{abstract}

Keywords: double monasteries; gender cohabitation; Orthodox monasticism; monastic rules

\section{Introduction}

This paper is a part of a broader research project on contemporary Orthodox monasteries that was initiated in January 2017 with the aim of analyzing the gender relationship in the Orthodox monasticism (Cozma and Giorda 2018a, 2018b; Giorda 2019). In particular, the project stems from the need to respond to the repeated affirmations of certain insiders (with, or without, roles of responsibility) of the Orthodox community regarding total separation of men and women within monasteries and the non-existence of monastic double communities, i.e., monasteries, including both communities of men and women, which were prohibited illo tempore by canonical and Byzantine law. Furthermore, this is a useful perspective in comparing Orthodox monasticism to Catholic monasticism, since the "lens" on gender relationship permits one to stress the historical differences between the two traditions. While the term "double monastery" and the corresponding prohibition is well-known and still in force in Orthodox monasticism, the term has not been used in Catholic monasticism. However, the practice of monasteries with double communities lasted for centuries in the Catholic west in practice, as multiple cases show, especially in France, Spain, Italy, and the United Kingdom (Elm and Parisse 1992).

From this standpoint, the St. John the Baptist Monastery of Essex, England presents a case, both for its architectural structure and its mixed composition, which constitutes an evident exception to the canonical norms that regulate the organization of Orthodox monastic life. Insiders affirm that this monastery is an example of an anecdotal reproduction stimulated by ancient monastic forms of organization and able to form a collective precept, as well as a cultural and social memory that have been sedimented and transmitted over the centuries (Fentress and Wickman 1992). Thus, despite the 
presence of monks and nuns residing in the same place at St. John the Baptist, we often hear from its defenders: "it is not a double monastery, because double monasteries do not exist".

The history of the de jure formalization process of the category of double/mixed/twin monasteries, and their relationship with the variety that de facto characterizes the coexistence of men and women in the same monastic place, is turbulent. The result has been the survival of different forms of this cohabitation since the very origins of monasticism, through the Byzantine period, and until today.

Therefore, this paper adds to the contemporary research regarding double monasteries in the Orthodox Christianity ambit (Bateson 1899; Pargoire 1906; Stoney 1915; Hilpisch 1928; Trone 1983; Konidaris 1990; Stramara 1998a, 1998b; Schipper 2005; Melvani 2016; Jugănaru 2018; Beach and Jugănaru forthcoming), and its main aims are (1) to demonstrate the vitality of a typology of gender monastic cohabitation, despite the canonical norms that prohibit it, as well as (2) to explore the arguments that defend/support the evidence of a phenomenon that is not only prohibited, but also denied.

\section{Methodology}

Before considering the history and sociology of the St. John the Baptist Monastery of Essex, it is first necessary to provide a methodological note in order to frame all of the research opportunities and difficulties encountered. The absence of both a complete bibliography and a well-structured website, as one would expect from an attractive and spiritual center of this kind, is notable (Jonveaux 2013).

Taking into consideration its genesis and objectives, this essay is based on an experimental methodology, both for the diachronic arc that led us to consider the phenomenon over a long period of time-more than 15 centuries - and for the instruments that were used for this research: historical and critical reading of sources (i.e., literary, documentary, and archaeological sources), interviews that were conducted to define the object of the research, and direct and indirect ethnographic investigations (Diéz et al. 2014).

The only official online information about the monastery can be found on the website of the Ecumenical Patriarchate of Constantinople, to which it belongs ( $w w w$.patriarchate.org/monasteryessex), and on the Facebook page of the monastery (www.facebook.com/monasterystjohnbaptistessex). Some scattered information can also be found on different websites and blogs. ${ }^{1}$

Faced with this quite fragmented information, we decided to contact the monastery by traditional mail, asking some general questions regarding the organization of the monastery and its daily monastic life. The answer came to us through a letter, which was dated 13 January 2018, and signed by Archimandrite Kyrill, abbot of the monastery, in which he refused to reply to the questions of external inquires (Kyrill 2018).

Therefore, this article draws upon written sources, and personal statements of visitors and frequent pilgrims of the monastery, as well as on a conspicuous bibliography that was produced within the monastic environment. Here, we also employ the concept of "indirect observation" that is based on analyzing textual material generated from narratives (i.e., letters, blogs, and emails) as well as interviews with people who frequented the monastery (Anguera et al. 2019). The most notable volume of this bibliography is the special issue of Buisson Ardent (Revue de l'Association Saint Saint Silouane l'Athonite), called Cahiers Saint Silouane l'Athonite, Hommage à l'Archimandrite Starez Syméon (2012). Important details regarding the genesis and the activities of the monastery have been deduced from the testimonials of several monks of the monastery, which include Rafail Noica, Syméon Brüschweiler, and Zacharias Zacharou (Drăgoi and Țugui 2002; Zacharias 2003; Syméon 2012). Lastly, the experiences of some people who have either visited the monastery as pilgrims, or that are linked to it through spiritual

1 www.thyateira.org.uk/monastery-of-st-john-the-baptist; www.patheos.com/blogs/orthodixie/2014/05/essex-monastery-ofst-john-the-baptist.html; www.rafailnoica.wordpress.com/2008/12/09/manastirea-sfantul-ioan-botezatorul-essex-angliaunde-a-vietuit-par-rafail-noica-sub-obladuirea-arhim-sofronie; www.londinoupolis.blogspot.it/2015/01/patriarchalstavropegic-monastery-of-st.html; www.greekamericangirl.com/a-pilgrimage-to-st-john-the-baptist-monastery-in-essexengland/. 
bonds (spiritual guidance, confession), were extremely helpful. We note especially here the testimonies of Daniela Dumbravă—a "spiritual daughter" of the monastery for almost 16 years (Dumbravă 2018a, 2018b, 2018c, 2019).

We consider this article to be a preliminary introduction to both the topic and case study due to the impossibility at this time to have direct interviews with monks and nuns of the monastery. It is also useful for framing some topics and to prepare the fieldwork, since we believe that it would be very important to know first its historical and theological background.

\section{History of the Monastery}

The monastery of St. John the Baptist was founded in 1959 at Tolleshunt Knights, within the area of Maldon District, in Essex county (northeast of London), England, by the Russian Archimandrite Sophrony Sakharov, disciple of the monk Silouan—canonized as a saint in 1987 by the Holy Synod of Ecumenical Patriarchate of Constantinople (Sophrony 1999).

Archimandrite Sophrony-Sergei Symeonovich Sakharov—was born on 23 September 1896 in Moscow. He studied art and painting at the Academy of Arts (1915-1917) and the Moscow School of Painting, Sculpture, and Architecture (1920-1921). In 1921, he left Russia and he settled in Paris in 1922 after a short journey to Italy and Germany. At that time, Paris was one of the major European cities with a large population of Russians, many of whom had escaped from Russia after the 1917 Revolution (Menegaldo 1998). The first phase of Sergei's sojourn in France was characterized by a period of spiritual research, including even some yoga courses. In 1924, on the Saturday before Easter, Sergei decided to change his life by moving towards a pragmatic Christianity that was centered on the efforts of man to know Jesus through prayer. In 1925, he began studying theology at the Saint Sergius Orthodox Theological Institute in Paris, but after a short time, in 1926, he abandoned his theological studies for the St. Panteleimon's Monastery in Mount Athos, Greece (a monastery with a dominant Russian ethnicity), wherein he received the monastic tonsure as Sophrony. In 1930, he was ordained to the diaconate, and in 1941 to the priesthood by Serbian bishop Nicolai Velimirovič of Zicha. In 1930, Sophrony began a close spiritual relationship with the staretz Silouan, which lasted until the staretz's death on 24 September 1938 (Sakharov 2002).

With regard to its canonical status, St. John the Baptist is a stavropegial monastery (Thomas 1987; Morris 1995), being directly subject to the Ecumenical Patriarchate of Constantinople and organized as a monastic community for both men and women. As far as we know, it is the only instance in the Orthodox Church recognized de jure and de facto as a monastery where two communities-male and female-share the topos and the roof of the same monastery.

The proto-history of the monastery goes back to the Athonite period of Sophrony, originating from his spiritual relationship with Silouan. Before his death, Silouan gave his disciple various writings that described his spiritual experiences. Although different semantically, but not spiritually, the handwritten texts of Silouan were similar to those that comprised in the spiritual testament left by Theodore Studites to his disciples in the IX century (Miller 2000; Giorda 2017b).

In Silouan's writings, a central theme was a practical ascetic life that was understood as "Adamic life". This theological term refers to the period of Adam and Eve before the Fall in Paradise when sexual attraction did not exist. Thus, monastic gender cohabitation is also a challenge that aims to reduce the passions and carnal desires by replacing them with communication and communion in spirit. That is why the notion of "Adamic life" is important, since it offers to us a better understanding of the other expressions often encountered in the Orthodox monastic typika, such as "the masculinization of the nuns", with reference here to a double monastery of the late 13th century, where its founder, Patriarch Athanasius I of Constantinople, accepted into monastery women who came to him "pour se viriliser", i.e., to be strengthened with masculine qualities (Delehaye 1897, p. 57).

The main idea of Silouan's ascetic path is that the love of God brings believers to the knowledge of God's will. In his thinking, knowing God means the experience of an organic communion, a real union with the Divine Light. Throughout this process, a man must have his heart preserved from all external 
influences, renouncing his own will and preparing himself for every sacrifice, "like Abraham-even like Christ Himself" (Sophrony 1999, p. 77). The exercise of pure prayer, especially the so-called "Prayer of Jesus" or "Prayer of the heart" (that is a prayer chiefly composed of invocation of the name of Jesus, accompanied by a confession of faith and the cry for mercy: "Lord Jesus Christ, Son of God, have mercy on me, a sinner"), is essential in this process, allowing for the mind to descend into the heart, filling it with the grace of the Holy Spirit, and transforming man into a true "theologian".

According to Silouan, the word "theologian" is not to be understood in an academic sense, but in a spiritual sense-namely, a theologian is anyone who practices pure prayer. He stated: "If you are a theologian, your prayer is pure. If your prayer is pure, then you are a theologian" (Sophrony 1999, p. 138). This recalls the teaching of Evagrius Ponticus on prayer: "If you are a theologian, you will pray truly. And if you pray truly, you are a theologian" (Evagrius 1983, p. 63). The maxim that constantly has accompanied Silouan's teaching has been, "keep your mind in hell and despair not" (Sophrony 1999, p. 210).

Sophrony immigrated back to Paris in 1947 due to health reasons, but also because of the situation that was created in Mount Athos after World War II, which led to a drastic limitation of the number of non-Greek monks at the Athonite monasteries (Sakharov 2002, pp. 28-29). This post-Athonite period was important for him. He settled in an old house in the Parisian suburb of Sainte Geneviève des Bois, which was then used at the time as a home for elderly Russian emigrants. In this period, Sophorny's main concern was making known, publishing, and putting into practice Silouan's teachings. His efforts came to fruition in September 1948, when the first edition of the staretz's notes was printed using the cyclostyle process. Ample comments with an impressive hermeneutic, dogmatic, and philosophical background, and brief bibliographic notes accompanied Silouan's writings. This edition was followed by a second one in 1952, in which Sophrony added a theological introduction to the writings of Silouan (Syméon 2012; Hierotheos Vlachos). This last edition, which was translated into English, German, French, and Greek, depicts the staretz Silouan as one of the most important contemporary spiritual fathers, while conferring significant credibility and spiritual authority to Sophrony.

The Parisian period gave Sophrony the opportunity to begin a spiritual journey that would culminate in the organization of an initial ascetic nucleus of men and women in 1956, and subsequently the transfer of this group to England and the foundation of the St. John the Baptist Monastery. Thus, for Sophrony, the prophetic words of Silouan that he received when he lived as a hermit in Karoulia, in the heart of Mount Athos, were coming true: "One day you yourself will distribute the obedience" (Monastere St. Jean Baptiste 2012, p. 11).

The move to England was mainly determined by several factors, as follows: the precarious conditions of the monastic community in Sainte Geneviève; the linguistic heterogeneity of the monastic group, which was increasing; and, not least, the attempt of some Orthodox theologians and intellectuals to isolate Sophrony due to his refusal to openly condemn the political complicity of the Moscow Patriarchate, whose leaders abandoned political opposition to the communist regime and pledged their loyalty and support (Bociurkiw 1959). He was also rejected by the St. Sergius Institute for his sympathies toward the Russian church and never completed his theological training (Sakharov 2002, pp. 30, 41-42).

Syméon Brüschweiler-who one of the first monks of Sophrony's community—and Rosemary Edmonds-who later became a nun at Essex-played an important role in the relocation of the community to England. It was Edmonds who recommended the place of the future monastery to Sophrony in 1958. The site was an ancient presbytery (the Old Rectory), which was located at Tolleshunt Knights, in the English county of Essex, an isolated place, put up for sale at a modest price due to its advanced state of deterioration. In the same year, Sophrony went to England to see the place and, with the blessing of Patriarch Alexy I of Moscow, he immediately decided to begin the formal purchasing process. The young monastic community of six people (four men and two women) moved from Paris to the new location on 5 March 1959 (Sakharov 2002, p. 34). Nevertheless, the advanced state of 
degradation did not allow for the use of the entire property; thus, the small community settled in the old parish house.

In spite of the monastic discipline of the group, they initially chose not to call themselves a monastery, but rather a community: The Community of Saint John the Baptist. Only a few months later, the Orthodox bishop Anthony Bloom, suffragan of the Patriarchate Exarchate of Western Europe (Moscow Patriarchate), blessed and approved the foundation of the monastery. In 1962, the monastery entered under the canonical jurisdiction of the newly established diocese of Great Britain and Ireland - that was known as the Diocese of Sourozh — to which Anthony was appointed as titular bishop. In 1964, due to some disagreements with Anthony, Sophrony asked Patriarch Alexy I of Moscow for his blessing to transfer the monastery to the jurisdiction of the Ecumenical Patriarchate. We have not found any explicit information regarding this crucial point of Sophrony's community. Nonetheless, it seems that the disagreement between them was more personal than institutional, and it was primarily determined by their different spiritual positions and monastic experiences (Dumbravă 2019). Thus, the monastery entered under the jurisdiction of the Ecumenical Patriarchate in 1965, and later received the status of stavropegial monastery (Sakharov 2002, p. 34; Sarni 2012, pp. 57, 61). Sophrony was the superior of the monastery until his death on 11 July 1993. Since 1993 the staretz and superior of the monastery has been Archimandrite Kirill, one of the disciples of Sophrony since his Athonite period.

\section{Liturgical Asceticism and Practice: A Monastic Habitus}

In monasticism, the word "habitus" expresses a spiritual sense, since it refers to a way of life common to both monks and laypersons, monastic families, and traditional families (Alciati and Giorda 2010; Giorda 2015, 2017a). As Greg Peters has recently shown, this way is rooted in baptism for it unifies all believers, whether monks or laics, essentially propelling them towards the same overall Christian goal: deification and union with God (Peters 2018, p. 110).

In Silouan's teachings, hesychasm does not necessarily mean living like a recluse, isolated in the desert, but primarily means living uninterruptedly with God, which should be a common way of life for all believers (Sophrony 1999, p. 141). The first spiritual group around Sophrony in Paris was formed on such ascetical reflection. Therefore, Sophrony did not seek to establish a formal monastic community, but rather to promote a type of asceticism that was focused on meditation of the mind and heart, in which the primary means are the Liturgy and the recitation of the Prayer of Jesus. Within this framework, the meaning of the monastic life was understood as a gift of the Holy Spirit, an imitation of the angelic life in the world (Zacharias 2003, pp. 127-29), and a school of life through which a man "passes from the individual status-i.e., from the fallen, divided, and atomized state- to the unity of the hypostasis of the person in communion with God and neighbor" (Syméon 2012, p. 45).

Therefore, from the beginning, Sophrony did not follow the regular structure of the Orthodox liturgical typikon, since he considered the inner perfection that was derived from the freedom of the person to be more important than the external conformity to a rule, which could cancel or suppress such freedom (Sakharov 2002, p. 34). In his words, "any spiritual act, performed under an external pressure and with no freedom, has no value before God's eyes. Therefore, everything we do in the monastic life must be wholly inspired by the love of God and neighbor, not simply derived from the observance of an external rule" (Syméon 2012, pp. 45-46).

In our view, such a spiritual life has attracted, and continues to attract, people with different cultural background, since it opens the possibility of expressing themselves in a liberal way, freely adapting the monastic rule, that is, a kind of (re)invention of the monastic tradition in everyday life, as Stefania Palmisano has demonstrated (Palmisano 2015).

During the Parisian period, the typikon included a simple rule of prayer as follows: O Heavenly King (a prayer addressed to the Holy Spirit), O most Holy Trinity, Our Father, some Psalms (of which including Psalm 50[51]), the Symbol of Faith, and the Jesus Prayer. This short rule of prayer is older 
than Silouan or Sophrony, and it is sometimes called the "Rule of St. Pachomius", (Brianchaninov 2005, p. 33), or "The Little Rule of St. Seraphim of Sarov" ( 2000; Puretzki 2017).

At the beginning of the English period of the monastery, the typikon included the Vigil (Hours, Vespers) and the Matins recited in Slavonic, followed by the Jesus Prayer, which was recited in Old Slavonic. The liturgical rhythm was completed by the celebration of the Divine Liturgy on Sundays, Saturdays, and on the most important feast days. In addition to the linguistic diversity in liturgical celebrations (Slavic, Ancient Greek, English, French, and Romanian), this typikon is currently completed by the recitation of the Paràklisi to Theotokos on Sundays, and by the special Lenten Hours during the Great Lent, which has slightly different liturgical rhythms from the ordinary liturgical period.

The liturgical life tout court is organized in two periods: the weekends and weekdays. On the weekends, the schedule is as follows: on Saturday at 7:00 a.m., the Matins, is celebrated, followed by the Divine Liturgy, and the Vigil is at 5 p.m. (Evening Hours, Vespers, and an Akathist Hymn); Matins and the Divine Liturgy are celebrated on Sunday, in two separate sets and places: from 7:00 a.m. to 10:30 a.m. in the St. Silouan Church (the former All Saints Chapel), and from 10:15 a.m. to 12:00 p.m. in the Old Church. The Vespers and Paràklisi to Theotokos are celebrated from 03:00 p.m. to 05:00 p.m. on Sundays. The weekday celebrations (from Monday to Friday), which are held from 6:00 a.m. (7:00 a.m. on Mondays) to 8:30 a.m. and from 5:30 p.m. to 8:00 p.m., are mainly based on the unceasing recitation of the Jesus Prayer in different languages. On Tuesday and Thursday, the Jesus Prayer is followed at 7:00 a.m. by the Divine Liturgy (Filip 2010; Dumbravă 2018b; Visiting St. John the Baptist Monastery, England. Orthodox in Malaysia 2018).

On feast days during the week, the celebration begins on the evening of the day before with the Vigil (Evening Hours, Vespers, and the Akathist Hymn to the saint or for the feast that is being celebrated), followed in the morning of the next day by Matins and the Divine Liturgy (Sokolof 2001, p. 35).

The linguistic and national heterogeneity of both the monastic group, which includes people from over 17 nationalities, and those attending the monastery have contributed to the implementation of the Jesus Prayer as a liturgical ritus (a form of common prayer), which is loudly recited by everyone in his own language up to four hours each day (except on Saturdays and Sundays), even replacing the usual ritual of the Hours.

With this typikon, Sophrony imparted his own spiritual rule of prayer (the Divine Liturgy and the Jesus Prayer) to the monastic community (and to others beyond the monastery) from his time as a monk at Mount Athos (Monastere St. Jean Baptiste 2012, p. 13). Nicholas Sakharov, who is Sophrony's nephew and a monk at Essex, noted that the substitution of the regular common services of the Hours in church (Matins, Vespers, Compline, Midnight Office) with the Jesus Prayer has a practical utility and it was not an unspoken invention of Sophrony. This typikon of prayer was indeed practiced by other Athonite monks, among which he recalled Nicodemus the Hagiorite and Paisy Velichkovsky. Nicholas emphasized: "this pattern was more appropriate to a small multinational community: reading services in one particular language would have excluded some (members as well as visitors) from full participation in the service" (Sakharov 2002, p. 34). Furthermore, we should have always in mind that the so called "Orthodox Diaspora" has a dominated ethnic character with multinational jurisdictions. This fact creates a particular situation within the Orthodox Church without precedent, which is characterized by two tendencies: (1) the affirmation of the Western local Orthodox Churches and (2) the preservation of specific national-ethnic Orthodox traditions. The latter is quite widespread at the local level (i.e., parishes and monasteries), not only in Western Europe, but also in the United States as well as over the Orthodox Diaspora. This best exemplified especially by liturgical celebrations held exclusively in the language of the national group which makes up that parish and frequents church events. Such tendency often transforms the church into an "enclave" only available to those who use the same language and share the same cultural and national traditions, i.e., Russians for Russians, Romanian for Romanians, Greeks for Greeks, Georgians for Georgians, Bulgarians for Bulgarians, etc. (Cozma 2018; Cozma and Giorda 2018c). In such instance, according to Alexander 
Schmemann, the Church becomes an "instrument of nationalism" (Schmemann 1964, p. 77), losing its missionary aim.

Therefore, in addition to promoting a spiritual unity, the Jesus Prayer as a common prayer is very important, because it intends to offer a unique identity to all participants, overcoming the inherent complications that are posed by a congregation of different linguistic, national, and gender identities. It is a monastic way of life that is not only reserved for monks, but it can be practiced in any place and by anyone: at the monastery, at home, by a whole family, by a group, or in private. Sophrony advised non-monastics to bring the monastery-with its goals, ideals, purity, faith, and experience-into their homes and their own lives, transforming their houses into churches (Dahulich 1997). This practice echoes John Chrysostom's teaching, who considered that every Christian family is in fact a "small Church" (PG² [Migne 1857-1866] 62, coll. 135-150).

Dumbravă $(2018 a, 2018 c)$ emphasized that this identity is also designed to create a kind of spiritual familiarity, in which the binomials of monk/layman and male/female become an integrated part of a normality that clearly reflects the doctrine of the two staretzes (Silouan and Sophrony). According to this doctrine, cohabitation is simply a detail of the monastic life, as compared to the requirements that they have to fulfill as monastics. The spiritual quality of the monastic existence puts the form of cohabitation of this monastic community in second place. In this sense, the answer of sister Mikhaila—one of the oldest nuns, and among the first in the Essex monastic community-to the question regarding the presence in the same place of a community of men next to one of women, is quite relevant: "Where do you see men around here? I do not see any man, but only brothers" (Dumbravă 2018b). This affirmation reveals that the monastic life is perceived by the St. John the Baptist monastic community as an angelic life, which the monk strives to reach in this world through continuous prayer, fasting, and repentance. The result of such a commitment is a highly spiritualized vision, in which men and women are perceived as angels, a status that precludes any sexual temptation.

Some monks and nuns do not follow the complete liturgical rhythm, but rather live in a semi-idiorrhythmic condition that frees them from regular participation at liturgical celebrations from Monday to Friday, in order to be able to dedicate themselves to translations and other writing works. This was Syméon's modus vivendi, but the Archimandrite Zacharias Zacharou and other senior members of the community (monks and nuns) also follow this program.

Among the activities within the monastery are the so-called Talks, which are organized every Sunday evening after the evening prayer (Vespers and Paràklisi): two lectures, each one hour long, one in Greek held in the St. Silouan Church, and one in English held in the vestibule of Hylands Refectory, which are followed by tea offered to all the participants. The topics of the lectures are usually chosen by speakers-typically a well-prepared nun, or a hieromonk.

Regarding the attendance of the non-monastics, every Sunday the monastery is visited by about 150-200 people, with most of them coming from nearby areas, including London and Colchester, and some from different countries. On average, around 10,000 people visit on Sundays throughout the year. According to interviews conducted within the monastery, both the new members of the monastic community and pilgrims have declared that they are attracted to this sacred place, due to its existential and pragmatic spirituality, which is more practical than theoretical and discursive. For who attends the monastery, this pragmatism gives to the place a unique spiritual legitimacy that is rarely found in other similar places (Filip 2010; Archos 2018; Dumbravă 2018c; Visiting St. John the Baptist Monastery, England. Orthodox in Malaysia 2018). Two months a year, the monastery is closed to the public for renovation and construction work on the pilgrim accommodations.

2 Jacques-Paul Migne, ed., Patrologiae Cursus Completus. Series Graeca (Parisiis: Migne 1857-1866). 


\section{Complexity of the Monastic Sacred Space}

This research is concerned with the peculiarity of the double structure of the community: men and women living together in the same monastery, sharing the same typikon, and, in certain cases, the same spaces. This is not only a simple restoration of an ancient monastic typology, but is also a modern way of living the monastic ascetical experience in the contemporary world, which-according to Sophrony-is characterized by the sobriety of the spirit and the silence of the intellect, as well as by hesychia, where the monastery, as topos, becomes a common place of prayer and penitence (Zacharias 2003, p. 129; Syméon 2012, p. 46; Burgat 2012, p. 192). Within this context, all of the details related to the genesis of the Essex monastic community are fundamental in understanding the reasons for gender cohabitation and the architectural partition of the monastic buildings.

The living spaces within the monastery were built and organized according to the evolving needs of the people living there, and were mainly determined by the increase in number of the monastic community, and only secondarily by the stream of pilgrims. Sophrony aimed not to draw attention to the monastery within the surrounding natural and architectural landscape since the beginning, neither as a cluster of buildings nor as a new form of organization. All of the buildings, including the places of worship, have a modest architectural form that is consistent with the urban planning style of the area and is also completely atypical when compared to the Orthodox churches and monasteries in Greece, Cyprus, Russia, Romania, Serbia, Bulgaria, Georgia, and Ukraine. Rather, extreme simplicity characterizes the monastery's buildings. Nonetheless, Sophrony's contribution to the architectural and aesthetic geometry of the monastery was quite significant. Sophrony's art and painting studies in Moscow, his brief experience as a painter in his youth, the lessons on iconography and church painting he took in Paris from the famous Russian icon painter and historian Léonide Ouspensky (Doolan 2008), and his Athonite experience, all served as inspiration as he reconfigured and adapted the buildings of the Old Rectory to Orthodox monastic needs. He painted icons first, and then painted the inside chapel walls and the refectory (trapeza) in fresco. On the refectory's walls he painted the main narrative scenes from the Gospel (i.e., the Transfiguration of Jesus, the Last Supper, the Crucifixion, the Resurrection, and the Pentecost) and some Old Testament scenes, including the appearance of the Holy Trinity to Abraham at the Oak of Mamre.

On the iconostasis of the Old Rectory chapel are icons painted by Léonide Ouspensky and monk Grégoire Krug (Syméon 2012, p. 42). Thanks to sister Maria, whose field of expertise is the art of mosaic making, there are mosaics that portray various Orthodox saints, such as St. Nicholas, and some biblical scenes, like the ark of Noah, St. Symeon of the Wonderful Mountain, and St. Kirill, on the external walls of the churches and some other buildings.

From an architectural perspective, the monastery is comprised of two structures: the male quarters and the female quarters, which a road separates. The male area contains the following buildings: the St. Silouan Church, the hegumen house (used for the accommodation of bishops and elderly guests), the Old Rectory (for young guests), the All Saints Chapel (with the tomb of Sophrony, and the house where he lived-currently inhabited by his nephew Nicholas), the rooms for the monks, various rooms for the work of the monks (ateliers), various gardens, the Bookstore, and a small trapeza, where breakfast is eaten. In the gardens, there are also various small houses where the monks can work or host male visitors. Today the male monastic community has 20 people, most of whom are novices. Men entering the community are prepared to be priests, spiritual fathers, and deacons, as well as witnesses and diffusers of the spiritual heritage of Sophrony and Silouan.

In the nuns' quarters, behind the gates that open each morning before 6:00 a.m. and close each night around 10 p.m., is the main refectory of the monastery, the nuns' dwellings, the working places for nuns, and the female guest rooms, which are located on the opposite side of the house and without connections to the nuns' rooms. In addition, for young women, there are two other guest houses that are located about one mile from the monastery, which are comprised of rooms for both nuns and female guests. For the female guests that are hosted there, the monastery provides a van driven by a nun. Women come to the monastery for liturgical offices, and beyond this, during their sojourn to the 
monastery, they offer a helping hand in the kitchen or in the garden. Forty women live in the female monastic community, of whom about half are novices (Dumbravă 2018a).

As it has already been emphasized, the double community was formed in nuce during the Parisian period, when Sophrony accepted both men and women to be part of his group. However, no information is available about the cohabitation form and the architectural structure of the buildings where this first community lived. It is only known that when the community moved to England, it was comprised of six people: four men (three of whom were monks) and two women.

The English location has permitted the organization of monastic life respecting gender separation: nuns and laywomen are not allowed to enter the monks' and male guests' spaces, and vice versa. Concerning this essential aspect of the monastic life, Archimandrite Syméon emphasized that, as in the Pachomius monastery, where men lived on one side of the river and women on the other side, the potamos (river) of Tolleshunt Knights Monastery is a road that separates the two communities (Syméon 2012, p. 45).

However, there are also common areas where men and women encounter each other daily to pray, eat, work, or socialize, including the St. Silouan Church; the All Saints Chapel; the two refectories (there is a convivial five o'clock meeting with biscuits, coffee, and herbal teas); some spaces on the first floor of the Old Rectory, including a small kitchen, the chapel, a small confession room, and Sophrony's office; Sophrony's crypt; the gardens; the parking lot; and, the rooms that were used for various activities and works.

The monastery's rules do not allow for children to be hosted on the monastery premises. Nonetheless, children are an integral part of the religious and social life that takes place on Saturdays, Sundays, and during the main feasts of the year. About 30-35 children attend the liturgical celebrations, together with their parents, and receive communion. Many of them come from London and its suburbs. The monastery is an international environment that is mostly dominated by the ethnic communities of Greeks, Cypriots, Romanians, Russians, and Ukrainians. Every year, more and more British people attend religious services, coming either through conversions to Orthodoxy, or as part of a mixed family. Sister Magdalena, a nun of British origin, is in charge of the children. She organizes various activities for them in the monastery. They often receive gifts, and special attention is given to each of them on their birthdays, when the entire monastic community joins with the guests to celebrate them.

The monastery environment, besides being adorned with a great variety of flowers and trees, is also characterized by the presence of cats, rabbits, squirrels, and birds, which are generously fed by monks and visitors. This is an ecological practice that perfectly integrates with the life of the monastery, together with the cultivation of organic vegetables and legumes (Theokritoff 2009).

\section{Monastic Gender Cohabitation in Antiquity: The Norms that Shaped the Ban}

St. John the Baptist Monastery's configuration refers to a history of relations between genders that is retraceable in a variety of de facto forms of proximity and coexistence, dating back to the very origins of Christian monasticism. Among all the renunciations that are required by those aspiring to monastic life, which inherent to matrimony has been the most evident, because it is based on the idea and practice of celibacy, sexual abstinence, virginity, and physical separation between men and women. Although the renunciation of family ties rivals the severity of that of matrimony, this kind of relationship has been correspondingly preserved and replicated inside of what has been defined as "the monastic family", in which kinship ties have been replaced by spiritual connections. This imitation has been most evident in the monastic language (i.e., brother, sister, spiritual father, spiritual mother) (Wipszycka 2009), but has also been present both in administrative organization, (i.e., communion and division of goods and works) and the architectonic structure of the monastic buildings (i.e., men and women devoted to ascetic living together either in the same house or separate buildings-canonically belonging to the same monastic community; the same worship place for both male and female communities).

The ancient monastic sources, e.g., Apophthegmata Patrum (PG 65, coll. 71-440), and Historia Lausiaca (PG 34, coll. 991-1260; Palladius 1964), reveal numerous cases of men and women (who were 
in many cases spouses, brothers, and sisters) sharing the monastic life, either living together or in close proximity to each other, in a multifaceted variety of mixed forms, differently explained and justified. In this approach, the starting point for all historical reflections on ancient monasticism is definitively the late period of ancient Egypt. It is the well-known ascetic path of Antony of Egypt (251-356), who, after giving to the poor all possessions, entrusted his sister to "some faithful women" (the virgins) and lived his initial ascetical experience in a village in close proximity to the house of the virgins (Athanasius 2003).

In Historia Lausiaca, Palladius tells the story of Amoun (HL 8: Palladius 1964)—a contemporary to Antony and one of the most famous monks of the Nitrian Desert-who, after being forced by his uncle to marry, managed to persuade his wife to live together in chastity. They decided to separate after 18 years of cohabitation: Amoun went into the inner mountain of Nitria, to the south of Lake Mareotis, where he built two rounded cells, while she founded a convent in her own house. Another remarkable case that was described by Palladius is that of Ammonius (HL 11), a contemporary to the bishop Timotheus of Alexandria (381-385), who, along with his three brothers and two sisters, went down to the desert, each living the monastic life in separate cells and keeping a distance from the others. It would not be right to pass over in silence Olympias: Palladius said of her that, although she was married for a few days, "she died a virgin, wife only of the Word of Truth" (HL 56).

These examples indicate that, in Late Antiquity, the monastic life did not necessarily imply the total separation and annihilation of family ties. Often, a simple family house became a common place of asceticism, a domus monastica for a man and a woman.

The figure of Pachomius (287-346/7) is decisive in the construction of a monastic typology technically that is defined by the term "cenobitism" (koinos bios), which is centered on the spiritual relationship between the master and his disciples, assuming peculiarities that have endured for many centuries (Giorda 2010, p. 86). This relationship was pivotal in the foundation of the first monastery at Tabennisi, a "deserted village" (Chitty 1995; Goehring 1996; Rapp 2006) that was situated on the bank of the Nile, which included both male and female communities, the latter established a short distance from that of men's community and under the leadership of Maria, Pachomius's sister (Bo 27 [The bohairic life of Pachomius]; G1 32 [The first Greek life of Pachomius]: Veilleux 1980). James Goering underscored that the female monastery of Tabennisi was not included in the number of monasteries that were listed by his sources, but instead was seen as a sister monastery of the male establishment (Goehring 1996, p. 278). Within the monastic federation (koinonia) that reinforced Pachomius's paternity, other female monastic communities were established (incorporated into the community) in close proximity to the male foundations, as follows: the convent of Tsmene (Tkahšmin), which was located on one side of the Nile river opposite the male monastery of Panopolis (Šmin) and founded by Pachomius himself (HL 33.1; $\left.G^{1} 134\right)$; and, the convent of Bechné, about a mile from the male monastery of Phbew (Pbow/Faou), this last being founded by Theodore, Pachomius's disciple and successor ( $G^{1}$ 134; Rapp 2011; Goehring 2017). According to the Life of Pachomius, "These monasteries were able to do the weaving of woolen garments, blankets, and other things, and also the spinning of raw flax for tunics" ( $\left.G^{1} 134\right)$.

As described in Pachomius's biographies and rules $\left(G^{1}, 32\right.$; HL 33; Precepts 143/Boon 1932; Veilleux 1981), the monastic life was often embraced by an entire family: the men entered a male monastery and the women a female convent. Notwithstanding the proximity of two communities, the contacts between men and women were substantially limited. No men, except for the appointed monks (e.g., the priest and the deacon, whose visits were limited to Sundays), were allowed to visit the women's monastery. A brother was permitted to visit his relatives (i.e., mother, sister, wife, daughter, or cousin) for a limited period of time only if he had a chaperone with him (a man of proven age and life) and in the presence of another sister, but he could not bring them anything, receive anything, or speak "about worldly matters" (G1 32; Precepts 143; HL 32).

Another important figure in this period was Basil of Caesarea (329/30-379), who is considered to be the legislator of cenobitic monasticism (Špidlik 2007, p. 262); the one "who brought order into the chaos 
of experimentation by creating communities and written precepts that were to set the standards for generations to come" (Elm 1994, p. 61). The first monastic settlement (called "fraternity/brotherhood" [adelphótes]) that was founded by Basil was around 358 in the region of Neocaesarea (in Pontus), in a mountain area surrounded on three sides by the river Iris and located very close (about five miles) to the monastery of Annesi where his sister Macrina and their brother Peter lived (Silvas 2007). These two monastic settlements, which were separated by the crest of the mountain but adjacent to each other, formed a monastic pole, becoming models for the monastic regulations that were laid out in his writings (Morison 1912, pp. 98-99).

However, because of the lack of literary descriptions and archaeological evidence, the only starting point in picturing how Basil's monasteries were architecturally structured is the monastery of Macrina, which was summarily described by Gregory of Nyssa in the Life of St. Macrina (PG 46, coll. 976-996; Gregory of Nyssa 2001). It was a monastery with one church and two separate communities: the virgins' quarters led by Macrina, and the men's quarters under the leadership of her brother Peter. From Gregory's testimonies, it appears that each of these quarters was comprised of several houses. For example, he talks about the house of the "great Macrina" (c. 16), and the house close to the house of Macrina (c. 24).

Although Basil promoted this system of monastic double communities, the gender relationships within monasteries were carefully outlined in his Rules (55 Longer Rules/Regulae fusius tractatae, and 318 Shorter Rules/Regulae brevis tractatae), clearly prescribing a segregationist approach. One example of this monastic typology is Rule 33 of the Longer Rules (PG 31, coll. 997-1000; Basil 1962), which deals with the meetings between monks/brothers and nuns/sisters, as well as between them and the laity. The meetings were only allowed after the time, the necessity, and the place were properly established. To avoid any suspicion, no less than two, and no more than three, had to be present on each side participating in the discourse. If one of the brethren had to speak of or listen to something bearing on some private matter, the issue had to be first communicated to the chosen representatives (persons of advanced age), who were then required to discuss the business with selected older members of the sisterhood (a Pachomian dejà $v u$ ), and the conversation could take place if it was deemed necessary only after their mediation.

The same approach appears in Rule 108 of the Shorter Rules (henceforth SR): the superior of the male quarters was not allowed to meet and talk to a nun from the female quarters without the knowledge of the superior mother, even though their conversations were required to be about faith (PG 31, col. 1156). Furthermore, SR 109 set limitations that were aimed at minimizing the meetings and the conversations between even the superior of the male community and the superior mother of the female community (PG 31, col. 1156).

Despite all of these prohibitions, the nuns' quarters were not completely isolated from the monks'; instead, it could be argued that the two communities were interdependent. The dependence of the female community on the male one was especially highlighted in the spiritual field, as confession was administered by senior brothers that were chosen to serve the spiritual needs of the female community—cf. SR 110 (PG 31, col. 1157), and also included an economic component-cf. SR 154 (PG 31, col. 1184).

However, SR 111 is of particular importance, as it underscores that the relationship between the superior mother and the superior father should not be one of subordination, but of harmonious cooperation, both being assisted and controlled by the council of elders of the brotherhood (PG 31, col. 1157).

Therefore, the location of the Basilian fraternities (or monasteries) within or on the outskirts of cities, and the double composition of the monastic communities (quarters for men and quarters for women), as well as the terminology that is used to describe intra-monastic and extra-monastic relationships (i.e., brothers, sisters, and fraternity) demonstrate that Basil's intent was not to isolate monasticism from the world, but rather to propose the monastic ideal as a spiritual model for the entire Church. Basil did not ever use the concept of "double monastery" for his fraternities. Moreover, 
words, such as "monk", "nun", and "monastery", which were in use in Egypt, are completely absent from his monastic rules (Morard 1974; Girardi 1981). However, in the years that followed, the Basilian cenobitism became more and more preeminent within the Byzantine monastic landscape.

The intervention of the Byzantine Emperor Justinian I (527-565) in monastic matters was also pivotal for both the organization and internal discipline of monasteries. On 18 January, 529, the emperor issued a law enforcing monastic segregation in order to prevent abuse and eliminate any suspicion of monks and nuns (Codex. Just. I.3.43: Krueger 1892, CIC I: pp. 29-30). The law forbade cohabitation, meetings, and conversations between laymen and nuns, as well as the cohabitation of monks and nuns in the same location. If there were more monks than nuns in a given location, the nuns had to move from that place to another (either to an existing female monastery, or a new one built for them). However, the monks had to move if the number of the nuns was greater or equal to the number of monks. In such cases, the common movable and immovable properties were proportionally divided between the two communities. Moreover, the decree forbade priests and deacons from living in the monasteries of nuns for which they were assigned by the bishop to perform liturgical services and pastoral activities.

The prohibitions regarding gender segregation in the monasteries were completed in 533 with new more explicit provisions in Novella 133: "No woman shall enter into a monastery for men, or a man in one for women, either out of respect of a descendent buried there or for any other reason, and especially if it is said that they have, perchance, a brother in the monastery, or a sister or any other relative. For monks have no relations on earth, since they are seekers of a celestial life (c. 3)". However, the novella allowed for two or three aprocrisiarii-preferably eunuchs, or advanced in years-to enter into the convents of women to conduct "business matters and administer the ineffable communion when it is time for that (c. 5)" (Schöll and Kroll 1963, CIC III: pp. 669-71; 672-74; Justinian 2008).

The norm had an imperative character: its motivation was expressed at the beginning of chapter 1, as follows: "But since some things have been reported to us which need a more comprehensive and firmer law [Decree of 529], we have justly come to make this law to perfect and supplement the former one (c. 1)" (Schöll and Kroll 1963, CIC III: pp. 667-68; Justinian 2008).

In 546, Justinian once again interfered with monastic matters by issuing a new decree-Novella 123. In chapter 36 of this new law, the emperor reiterated the previous prohibitions concerning monastic gender cohabitation (i.e., Decree of 529, Novella 5, and Novella 133), but, above all, he introduced a previously unused technical term: "double monasteries" (dipla monastéria). Through this term, the emperor appears to have summarized the various monastic typologies of cohabitation that existed in that time (Cozma and Giorda 2018a). However, Justinian does not clearly explain what this term, "double monasteries", means, and what elements would define such an arrangement, which was henceforth prohibited. The prohibition of such monasteries is absolute: "We do not permit monks and nuns to live in the same monastery anywhere in our empire and do not permit the so-called double monasteries [emphasis mine] to exist" (Schöll and Kroll 1963, CIC III: p. 619; Justinian 2008).

The ambiguity of the expression "double monasteries" made the norm less effective in its practical application despite the decree's imperative character. Jules Pargoire noted that, beyond Constantinople and the neighboring areas, Justinian's law remained unenforced in the other provinces of the Byzantine Empire (Pargoire 1906, p. 22). For Ioannis Konidaris and Friedrich Schipper, the prohibition referred rather to mixed monasteries only, namely to those communities of monks and nuns that were living together in the same place without an effective mechanism for gender segregation (Konidaris 1990; Schipper 2005).

The intervention of the Church in the monastic cohabitation matter was explicitly considered at the Council in Trullo of 692. Canon 47 of this council, echoing Novella 133 of Justinian (women were prohibited to enter into male monasteries), prohibited women from sleeping in male monasteries, and vice versa, under the penalty of excommunication (Agapios and Nicodemos 1957, p. 347). The Trullan norm was later repeated in Canon 18 of the Seventh Ecumenical Council of Nicea (787), which forbade women from dwelling at diocesan headquarters, as well as in men's monasteries (Agapios and 
Nicodemos 1957, p. 446). However, the significance of the Council of Nicea is above all given in Canon 20. The Justinian term "double monastery" is used for the first time in this canon: "As from now on we decree that no double monastery [emphasis mine] is to be made, because this becomes a scandal and offense to many persons" (Agapios and Nicodemos 1957, p. 448).

This canonical provision-which it is still in force in the Byzantine Orthodox Churches-has prevented the cohabitation (permanent or temporary) of monks and nuns in the same monastery, and also the foundation of new monasteries with double communities (even if segregated), or, according to Ioannis Zonaras (Rhallis and Potlis 1852, pp. 868-69), the founding of two monasteries (one of monks and one of nuns) that are close to each other. However, the norm appears to refer not to a single form of monastic cohabitation, but to diverse typologies, among which, according to Theodore Balsamon, did not exclude mixed monasteries (Rhallis and Potlis 1852, pp. 639-40).

Despite Canon 20 and further prohibitions mandated by the patriarchs of Constantinople, such as Nicephorus I (806-815) and Alexios Studites (1025-1043) — both decreeing that the monk communities had to be moved far away from those of nuns (Janin 1964, p. 8; Parrinello 2012, p. 144; Garland 2013, pp. 31-32)-double monasteries have continued to exist in Byzantine monastic practice in the centuries that followed. In the late IXth century, Euthymius the Younger (824-898) founded a double monastery near Thessaloniki that was directed by his family: his nephew was abbot of the male monastery and his niece of the female convent (Talbot 1990, p. 123).

In Constantinople, in the early 12th century, there were two contiguous monasteries that were separated by a wall: one for men (Christos Philantropos) and one for women (Panagia Kecharitomene), founded around 1100-1007 by the emperor Alexios I Kommenos (1081-1118) and his wife Irène Doukaina, and situated on the northwest of the city (Janin 1964; Talbot 1998; Stramara 1998b). However, from the typicon of the female monastery (dating around 1110-1116), it appears that the two monasteries, despite their proximity, shared nothing, except for the separation wall and a water pipe.

Another example of a double monastery in Constantinople was the Christos Philantrophos Soter monastery, which was established in 1307 by Irène Choumnaina Palaiologina and situated on the eastern side of the city (Melvani 2016). This monastery was a legal entity with two segregated communities (male and female), under a single administration, and it shared some activities (Trone 1983; Talbot 1985, 2000).

Patriarch Athanasius I of Constantinople (1289-1293/1304-1310) at first condemned double monasteries, but later founded two similar monasteries: Nea Mone in Mount Ganos in Thrace (west of the Sea of Marmara) and Xerolophos in Constantinople (Talbot 1985; Mitsiou 2008).

After the fall of Constantinople in 1453, the only information regarding the existence of a double monastery is found in the life of St. Philotheos of Mount Athos. Philotheos and his brother received the monastic tonsure in the monastery of Neapolis (now Kavalla in Greece) around 1540, and their mother, Eudokia, also lived in the female quarters of this monastery (Talbot 1990, p. 123).

The Post-Byzantine and Modern periods, at least according to the plan prescribed by the Orthodox Canon Law, have both been characterized by an exclusive monastic typology in which gender segregation has been enforced and the foundation of monasteries with double communities has not been allowed by the Church authority.

However, places of cohabitation and encounter between monks and nuns have not ceased to exist in the Orthodox Church, albeit in limited numbers and in various forms: cohabitation of monks and nuns at bishoprics; monks and nuns working together at hospitals, nursing homes for the elderly, homes for orphans, and help centers for addicts, inside or outside of monasteries; and, monks and nuns living in segregation at a certain distance from each other, while affirming the spiritual paternity of the same founder or spiritual father (Cozma and Giorda 2018a, 2018b; Giorda 2019). Within this framework, the Essex monastery is an obvious expression of physical and spiritual proximity between monks and nuns in the contemporary world. 


\section{Conclusions}

The proximity of men and women in the monastic environment can be found in a variety of typologies of cohabitation, which can hardly be described by formulated definitions and proposed rigid delimitations. Despite the difficulties of defining the forms, the monastic language has, from the beginning, sanctioned terms and concepts that intended to facilitate a better understanding of the life of those who, in abandoning the world and the family, were faced with a new life, moving from a blood (i.e., socio-institutional) family to a spiritual one.

This perspective is vital in understanding the modalities through which cohabitation has been justified in both ancient and present-day Orthodox monasticism. The dignity of both sexes has never been understood through the modern lens of gender equality, namely in terms of equality of woman with man, but rather as a joint pathway toward the recovery of the original state of the first humans, prior to the Fall (Barone Adesi 1989, p. 272).

Byzantine (Justinian) and the Church norms (i.e., canons of the ecumenical councils, and monastic rules) both did not exclude the spiritual aspect of cohabitation; indeed, the prohibitions regarding the external form of cohabitation (whether mixed or double) were envisioned in order to safeguard the spiritual pathways of both genders. In this civil and canonical structure, total segregation was established as a rule, and gradually the double, mixed, and twin monasteries, as well as the places of proximity and cohabitation between monks and nuns began to diminish, only surviving in a fossilized condition. The Post-Byzantine period was characterized by a strong observance of the canonical norms, confidently stated in terms of the "Tradition of the Orthodox Church", which were considered, without question, not to be ignored, modified, or reinterpreted.

In the contemporary period, due in part to the desire to re-evaluate the modus vivendi of the ancient Fathers, but also to the widespread interest in the ascetic practice and ways of living of many people in the Orthodox Church, there has been an attempt to return to the spirit and practice of the Church of the early centuries. It is in this context that we must view the (re)foundation of monasteries with double communities, such as that of St. John the Baptist of Essex in England, with the same typikon and in certain cases sharing in a de facto form both liturgical or common spaces, or such as that of the New Skete in Cambridge, New York (1966), under the jurisdiction of the Orthodox Church in America, which is comprised of a community of monks and one of nuns that are located a couple of miles away from each other (https://newskete.org), or of two monasteries-one for men (1972) and one for women (1987) - being very close to each other, such as those of Panorama in Greece, under the jurisdiction of the Church of Greece (http://www.agia-triada-panorama.gr), or the most recent Our Lady and St. Laurence Monasteries in Cañon City, Colorado (2015), which is a Western rite monastic double community of monks and nuns under the Antiochian Orthodox Christian Archdiocese of North America (http://saintlaurenceosb.org).

Rather than rigidly interpreting this trend as a violation of Church laws (holy canons, imperial laws, and patriarchal decrees), it can be seen as a pastoral way of interpreting and employing the canonical norm, which is known in the Orthodox Church as oikonomia. Such a pastoral method allows for the authority of the Church to apply a permanent or temporary derogation from a canonical prescription (Erickson 1977).

In spite of a still-active canonical ban, and a certain formal duplicity, and notwithstanding those who are aligned with these traditions, and thus deny the existence today of double monasteries or of those monasteries that are characterized by a form of mixité, the de facto reality demonstrates the presence of such forms of cohabitation, which are theologically and canonically justified through spiritual terms, such as obedience, humility, and a struggle against the passions, as well as utility, and mutual spiritual and material interdependence. For this reason, St. John the Baptist Monastery can be traced back to the diverse forms of cohabitation between men and women of ancient monasticism, as the sources abundantly demonstrate. The example analyzed in this article is emblematic, because it is the only Orthodox monastery with two monastic communities that live in the same space, which is also active in the lives of the faithful both at the local/national and transnational level (Roudometof 
2015), in that both male and female visitors live temporarily at the monastery and attend the liturgical services. Furthermore, the widespread devotion to monasticism in Orthodoxy makes the monastery a model to follow for the Christian family, since the monastic pattern (characterized by prayers, penances, fasting, and sexual abstinence) is encouraged for the sanctity of the spouses.

An in depth-analysis of the collective narratives and theological arguments that support this monastic pattern of cohabitation (despite the Church rules) would be an important research path in the future for justifying the contemporary reasons for accepting this reality and analyzing the (possible) transformations of the monastic vision and monastic practice as regards the female gender (Jonveaux 2015).

Furthermore, it will be interesting to compare the history and sociology of some ancient and contemporary double monasteries (Orthodox and Catholic) in order to analyze similar practices in diverse monastic contexts, as well as to reflect on the continuity and discontinuities from both a chronological and comparative point of view.

Author Contributions: M.C.G. conceived the research project, elaborated the main ideas, and established the methodology; M.C.G. and I.C. collected the data, investigated and performed the analysis as well as wrote and reviewed the original draft. All authors read and approved the final manuscript.

Funding: This research received no external funding.

Conflicts of Interest: The authors declare no conflict of interest.

\section{References}

Agapios and Nicodemos. 1957. The Rudder (Pedalion): Of the Metaphorical Ship of the One Holy Catholic and Apostolic Church of the Orthodox Christians or All the Sacred and Divine Canons. Translated by Denver Cummings. Chicago: Orthodox Christian Educational Society.

Alciati, Roberto, and Maria Chiara Giorda. 2010. Famiglia cristiana e pratica monastica (IV-VII Secolo). Annali Di Storia Dell'esegesi 27: 265-90.

Anguera, M. Teresa, Mariona Portell, Salvador Chacón-Moscoso, and Susana Sanduvete-Chaves. 2019. Indirect Observation in Everyday Contexts: Concepts and Methodological Guidelines within a Mixed Methods Framework. Frontiers in Psychology 9: 1-20. Available online: https://doi.org/10.3389/fpsyg.2018.00013 (accessed on 25 June 2019).

Archos, Irene. 2018. A Pilgrimage to St. John the Baptist Monastery in Essex, England. Greek American Girl (blog). March 22. Available online: https://greekamericangirl.com/a-pilgrimage-to-st-john-the-baptist-monasteryin-essex-england/ (accessed on 10 May 2019).

Athanasius. 2003. The Life of Antony. Translated by Tim Vivian. Kalamazoo: Cistercian Publications.

Barone Adesi, Giorgio. 1989. Monachesimo Ortodosso d'Oriente e Diritto Romano Nel Tardo Antico. Milano: Giuffrè. Basil, Saint. 1962. Ascetical Works. Translated by Monica M. Wagner. Washington, DC: The Catholic University of America Press.

Bateson, Mary. 1899. Origin and Early History of Double Monasteries. Transactions of the Royal Historical Society 13: 137-98. [CrossRef]

Beach, Alison, and Andra Jugănaru. forthcoming. The Double Monastery as an Historiographical Problem. In The Cambridge History of Medieval Monasticism in the Latin West. Edited by Alison Beach and Isabelle Cochelin. Cambridge: Cambridge University Press.

Bociurkiw, Bohdan R. 1959. Church and State in the Soviet Union. International Journal 14: 182-89. [CrossRef]

Boon, Amand. 1932. Pachomiana Latina: Règle et Épitres de s. Pachome, Épitre de s. Théodore et "Liber" de s. Orsiesius. Louvain: Bureaux de la Revue.

Brianchaninov, Ignatius. 2005. On the Prayer of Jesus: The Classical Guide to the Practice of Unceasing Prayers Found in The Way of a Pilgrim. Translated by Father Lazarus. Boston and London: New Seeds.

Burgat, Pierre. 2012. Le Starets Syméon à La Côte-Aux-Fées, in Cahiers. In Cahiers Saint Silouane l'Athonite, Hommage à l'Archimandrite Starez Syméon (1928-2009). Edited by Jean-Claude Polet. Buisson Ardent. Horse-Série. Paris: Cerf, pp. 183-93.

Chitty, Derwas J. 1995. The Desert a City: An Introduction to the Study of Egyptian and Palestian Monasticism under the Christian Empire. Crestwood: St. Vladimir's Seminary Press. 
Cozma, Ioan. 2018. Canonical and administrative issues relating to the Parish in the Romanian Orthodox Episcopate of America. In Patrimoniul Cultural Religios_Legislatie si Jurisprudenta (Religious Cultural Heritage-Legislation and Jurisprudence). Edited by Marius Balan and Emilian Iustinian Roman. Iasi: Editura Universitatii “Alexandru Ioan Cuza" Iasi, pp. 225-42.

Cozma, Ioan, and Maria Chiara Giorda. 2018a. Uomini e donne nei monasteri: La genesi tardo antica di un equivoco. Rivista Di Storia Del Cristianesimo 15: 25-56.

Cozma, Ioan, and Maria Chiara Giorda. 2018b. Sede episcopale e monastero: Un caso inedito di coabitazione istituzionale e amministrativa nel monachesimo ortodosso contemporaneo. Annali Si Studi Religiosi 19: 115-39.

Cozma, Ioan, and Maria Chiara Giorda, eds. 2018c. Ortodossi Romeni d'Italia. Torino: Quaderni di Benvenuti in Italia 13.

Dahulich, Michael G. 1997. A Modern-Day Saint and His Disciple: Saint Silouan and Father Sophrony. Alive in Christ. The Magazine of the Diocese of Eastern Pennsylvania 13: 55-61.

Delehaye, Hyppolite. 1897. La Vie d'Athanase, Patriarche de Constantinople (1289-1293; 1304-10). Mélanges d'archéologie et d'histoire de l'Ecole Française de Rome 17: 39-75.

Diéz, Javier Gonzales, Maria Chiara Giorda, and Sara Hejazi. 2014. Studying Monasticism in Italy: An Anthropological and Historical Perspective. Annual Review of The Sociology of Religion, Sociology of Monasticism, Between Innovation and Tradition 5: 241-60.

Doolan, Patrick. 2008. Recovering the Icon: The Life and Work of Leonid Ouspensky. Crestwood: St. Vladimir's Seminary Press.

Drăgoi, Eugen, and Ninel Țugui. 2002. Celălalt Noica: Mărturii Ale Monahului Rafail Noica Însoțite de Câteva Cuvinte de Folos Ale Părintelui Symeon, 3rd ed.București: Anastasia.

Dumbravă, Daniela. 2018a. Email to Ioan Cozma and Maria Chiara Giorda: “Domande Essex: St. John the Baptist Monastery". January 24.

Dumbravă, Daniela. 2018b. Email to Ioan Cozma and Maria Chiara Giorda: "Stavropegiac Monastery of St. John the Baptist". February 13.

Dumbravă, Daniela. 2018c. "Monastic life at Essex: Interview with Daniela Dumbravă." By Ioan Cozma. Roma. November 22.

Dumbravă, Daniela. 2019. Email to Ioan Cozma and Maria Chiara Giorda: “Essex". July 3.

Elm, Susanna. 1994. Virgins of God: The Making of Asceticism in Late Antiquity. New York: Oxford University Press.

Elm, Kaspar, and Michel Parisse, eds. 1992. Doppelklöster und Andere Formen der Symbiose Männlicher und Weiblicher Religiosen im Mittelalter: (Ordensstudien VIII), 1st ed. Berlin: Duncker \& Humblot.

Erickson, John H. 1977. Oikonomia in Byzantine Canon Law. In Law, Church, and Society. Edited by Kenneth Pennington and Robert Somerville. Philadelphia: University of Philadelphia Press, pp. 225-36.

Evagrius, Ponticus. 1983. On Prayer. In Philokalia. Edited by Nikodimos of the Holy Mountain and Makarios of Corinth. vol. 1, Translated by Gerard Eustace H. Palmer, Philip Sherrard, and Kallistos Ware. London and Boston: Faber and Faber. Available online: https://archive.org/details/Philokalia-TheCompleteText/page/n33 (accessed on 21 May 2019).

Fentress, James, and Chris Wickman. 1992. Social Memory. Cambridge: Blackwell.

Filip, Gabriela. 2010. Cu Nepsis La Londra Si in Pelerinaj La Manastirea Sfantul Ioan Botezatorul, Essex. Apostolia. Available online: https://www.apostolia.eu/articol_67/cu-nepsis-la-londra-şi-in-pelerinaj-la-manastireasfantul-ioan-botezatorul-essex.html (accessed on 12 April 2019).

Garland, Lynda. 2013. Till Death Do Us Part?: Family Life in Byzantine Monasteries. In Questions of Gender in Byzantine Society. Edited by Bronwen Neil and Lynda Garland. London: Ashgate, pp. 29-56.

Giorda, Maria Chiara. 2010. Monachesimo e Istituzioni Ecclesiastiche in Egitto. Bologna: Dehoniane.

Giorda, Maria Chiara. 2015. Familles du «monde», familles monastiques. Une économie du capital dans l’Égypte chrétienne (Ve-VIe Siècles). «Archives Des Sciences Sociales de Religions» 17: 263-87.

Giorda, Maria Chiara. 2017a. Famiglie Monastiche. Il Dominus Tecum Di Pra'd Mill. Torino: Aragno.

Giorda, Maria Chiara. 2017b. Writing Monastic Testaments: A Communication from Generation to Generation. In Writing and Communication in Early Egyptian Monasticism. Edited by Malcom Choat and Maria Chiara Giorda. Texts and Studies in Eastern Christianity 9. Leuven: Brill, pp. 129-50.

Giorda, Maria Chiara. 2019. Monaci e Monache Presso Le Sedi Vescovili. Alcuni Casi Di Convivenza Nel Monachesimo Ortodosso Romeno. Studi e Materiali per La Storia Delle Religioni 85: 244-69. 


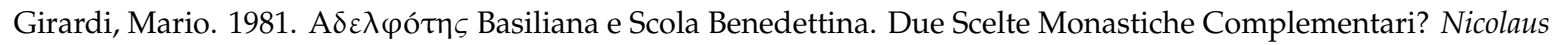
9: 3-61.

Goehring, James E. 1996. Withdrawing from the Desert: Pachomius and the Development of Village Monasticism in Upper Egypt. The Harvard Theological Review 89: 267-85. [CrossRef]

Goehring, James E. 2017. The Pachomian Federation and Lower Egypt: The Ties That Bind. In Christianity and Monasticism in Northern Egypt: Beni Sueff, Giza, Cairo, and the Nile Delta. Edited by Gawdat Gabra and Hanny N. Takla. Cairo and New York: The American University in Cairo Press, pp. 49-60.

Gregory of Nyssa. 2001. The Life of Saint Macrina. Edited by Kevin Corrigan. Toronto: Peregrina Publishing Co.

Hierotheos (Vlachos). 2015. I Know a Man in Christ: Elder Sophrony the Hesychast and Theologian. Levadia: Holy Monastery of the Birth of the Theotokos.

Hilpisch, Stephanus. 1928. Die Doppelklöster; Entstehung Und Organisation. Münster in Westf: Aschendorff.

Janin, Raymond. 1964. Le Monachisme Byzantin Au Moyen Âge. Commende et Typica (Xe-XIVe Siècle). Revue Des Études Byzantines 22: 5-44. [CrossRef]

Jonveaux, Isabelle. 2013. Dieu En Ligne: Expériences et Pratiques Religieuses Sur Internet. Montrouge: Bayard.

Jonveaux, Isabelle. 2015. Les Moniales et l'emprise Du Genre. Enquête Dans Des Monastères Catholiques de Femmes. Sociologie 6: 121-220. [CrossRef]

Jugănaru, Andra. 2018. Family Double Monasteries in the Fourth and the Fifth Centuries: An Inquiry into the Theological Roots, Social Context, and Early Evolution of an Old Practice. Ph.D. dissertation, Central European University, Budapest, Hungary. Available online: http://www.etd.ceu.edu/2018/juganaru_andra. pdf (accessed on 12 April 2019).

Justinian. ; Translated by Justice Fred H. Blume. 2008. Novels, 2nd ed. Available online: http://www.uwyo.edu/ lawlib/blume-justinian/ajc-edition-2/novels/121-140/novel\%20133_replacement.pdf (accessed on 30 May 2019).

Konidaris, Johannes M. 1990. Die Novelle 123 Justinians und das Problem der Doppelklöster. Subseciva Groningana (Studies in honor of Nicholas van der Wal) 4: 105-16.

Krueger, Paulus, ed. 1892. Corpus Iuris Civilis. Codex Iustinianus. Berolini: Apud Weidmannos, vol. 2.

Kyrill. 2018. Personal Letter to Maria Chiara Giorda. January 13.

Melvani, Nicholas. 2016. The Duplication of the Double Monastery of Christ Philanthropos in Constantinople. Revue Des Études Byzantines 74: 361-84.

Menegaldo, Héléne. 1998. Les Russes à Paris: 1919-39. Paris: Autrement.

Migne, Jacques-Paul, ed. 1857-1866. Patrologiae Cursus Completus. Series Graeca. Parisiis: Migne, vols. 26, 31, 34, $46,62,65$.

Miller, Timothy. 2000. Theodore Studites: Testament of Theodore the Studite for the Monastery of St. John Stoudios in Constantinople. In Byzantine Monastic Foundation Documents: A Complete Translation of the Surviving Founders' Typika and Testaments. Edited by John Ph. Thomas and Angela Constantinides. Dumbarton Oaks 35. Washington, DC: Dumbarton Oaks Research Library and Collection, pp. 67-83.

Mitsiou, Ekatherini. 2008. Das Doppelkloster Des Patriarchen Athanasios I. in Konstantinopel: Historisch-Prosopographische Und Wirtschaftliche Beobachtungen. Jahrbuch Der Österreichischen Byzantinistik 58: 87-106. [CrossRef]

Monastere St. Jean Baptiste. 2012. Moine à Tolleshunt Knights. In Cahiers Saint Silouane l'Athonite, Hommage à l'Archimandrite Starez Syméon (1928-2009). Edited by Jean-Claude Polet. Buisson Ardent. Horse-Série. Paris: Cerf, pp. 11-24.

Morard, Françoise. 1974. Monachos, Moine Histoire du Terme grec Jusqu'au 4e Siècle: Influences Bibliques et Gnostiques. Fribourg: Paulus-Verlag.

Morison, Ernest Frederick. 1912. St. Basil and His Rule; a Study in Early Monasticism. New York: H. Frowde.

Morris, Rosemary. 1995. Monks and Laymen in Byzantium, 843-1118. New York: Cambridge University Press.

Palladius. 1964. The Lausiac History. Edited by Robert T. Meyer. New York: Newman Press.

Palmisano, Stefania. 2015. Exploring New Monastic Communities: The (Re)invention of Tradition. Burlington: Ashgate. Pargoire, Jules. 1906. Les monastères doubles chez les Byzantins. Revue des Études Byzantines 9: 21-25. [CrossRef] Parrinello, Rosa M. 2012. Il Monachesimo Bizantino. Roma: Corocci.

Peters, Greg. 2018. The Monkhood of All Believers: The Monastic Foundation of Christian Spirituality. Grand Rapids: Baker Academic.

Puretzki, Nikolai. 2017. Life and Teaching of Saint Seraphim of Sarov. The Hague: Gozalov Books. 
Rapp, Claudia. 2006. Desert, City, and Countryside in the Early Christian Imagination. Church History and Religious Culture 86: 93-112. [CrossRef]

Rapp, Claudia. 2011. Early Monasticism in Egypt. In Female Vita Religiosa between Late Antiquity and the High Middle Ages: Structures, Developments and Spatial Contexts. Edited by Gert Melville and Ann Müller. Wien and Berlin: Lit, pp. 21-42.

Rhallis, Georgios Alexandros, and Michael Potlis. 1852. Syntagma tōn theiōn kai hierōn kanonōn. Athens: Chartophylakos, vol. 2.

Roudometof, Victor. 2015. Orthodox Christianity as a Transnational Religion: Theoretical, Historical and Comparative Considerations. Religion, State and Society 43: 211-27. [CrossRef]

Sakharov, Nicholas V. 2002. I Love Therefore I Am: The Theological Legacy of Archimandrite Sophrony. Crestwood: St. Vladimir's Seminary Press.

Sarni, Michael. 2012. The Russian Church in London. From Peter the Great to the Present Day. London: Arefa.

Schipper, Friedrich. 2005. 'Wir Erlauben Nicht, Dass in Einem Kloster Mönche Und Nonnen Wohnen' (Just. Nov. 123.36): Doppelklöster Im Spätantiken Ostmediterranen Raum. Kanon 17: 56-77.

Schmemann, Alexander. 1964. Problems of Orthodoxy in America. 1. The Canonical Problem. St. Vladimir's Seminary Quarterly 8: 67-85.

Schöll, Rudolf, and Wilhelm Kroll, eds. 1963. Corpus Juris Civilis. Novellae. Berlin and Zürich: Weidmann, vol. 3.

Silvas, Anna M. 2007. In Quest of Basil's Retreat: An Expedition to Ancient Pontus. Antichthon 41: 73-95. [CrossRef]

Sokolof, Dmytri. 2001. A Manual of The Orthodox Church's Divine Services. Jordanville: Holy Trinity Monastery.

Sophrony, Archim. 1999. Saint Silouan, the Athonite. Crestwood: St. Vladimir's Seminary Press.

Špidlik, Thomas. 2007. Il Monachesimo Secondo La Tradizione Dell'Oriente Cristiano. Roma: Lipa.

Stoney, Constance. 1915. Early Double Monasteries a Paper Read before the Heretics' Society on December 6th, 1914. London: G. Bell \& Sons.

Stramara, Daniel F. 1998a. Double Monasticism in the Greek East, Fourth through Eighth Centuries. Journal of Early Christian Studies 6: 269-312. [CrossRef]

Stramara, Daniel F. 1998b. Double Monasticism in the Greek East: Eighth through Fifteenth Centuries. The Greek Orthodox Theological Review 43: 185-202.

Syméon, Archim. 2012. Génération Du Monastère Saint Jean Baptiste. In Cahiers Saint Silouane l'Athonite, Hommage à l'Archimandrite Starez Syméon (1928-2009). Edited by Jean-Claude Polet. Buisson Ardent. Horse-Série. Paris: Cerf, pp. 40-47.

Talbot, Alice-Mary Maffry. 1985. A Comparison of the Monastic Experience of Byzantine Men and Women. The Greek Orthodox Theological Review 30: 1-20.

Talbot, Alice-Mary Maffry. 1990. The Byzantine Family and the Monastery. Dumbarton Oaks Papers 44: 119-29. [CrossRef]

Talbot, Alice-Mary Maffry. 1998. Women's Space in Byzantine Monasteries. Dumbarton Oaks Papers 52: 113-29. [CrossRef]

Talbot, Alice-Mary Maffry. 2000. Philanthropos: Typikon of Irene Choumnaina Palaiologina for the Convent of Christ Philanthropos in Constantinople. In Byzantine Monastic Foundation Documents: A Complete Translation of the Surviving Founders' Typika and Testaments. Edited by John Ph. Thomas and Angela Constantinides. Dumbarton Oaks 35. Washington, DC: Dumbarton Oaks Research Library and Collection, pp. 1383-88.

The Holorogion, or Book of Hours. 2000. South Canaan: St. Tikhon's Seminary Press.

Theokritoff, Elizabeth. 2009. Living in God's Creation: Orthodox Perspectives on Ecology. Crestwood: St. Vladimir's Seminary Press.

Thomas, John Philip. 1987. Private Religious Foundations in the Byzantine Empire. Dumbarton Oaks 24. Washington, DC: Dumbarton Oaks Research Library and Collection.

Trone, Robert. 1983. A Constantinopolitan Double Monastery of the Fourteenth Century: The Philanthropic Savior. Byzantine Studies 10: 81-86.

Veilleux, Armand, ed. 1980. Pachomian Koinonia: The Life of Saint Pachomius and His Disciples. Kalamazoo: Cistercian Publications, vol. 1.

Veilleux, Armand, ed. 1981. Pachomian Koinonia: Pachomian Chronicles and Rules. Kalamazoo: Cistercian Publications, vol. 2. 
Visiting St. John the Baptist Monastery, England. Orthodox in Malaysia. 2018. Available online: https: //orthodoxinmalaysia.wordpress.com/2018/06/24/visiting-st-john-the-baptist-monastery-england/ (accessed on 4 July 2019).

Wipszycka, Ewa. 2009. Moines et Communautés Monastiques En Égypte (IVe-VIIIe Siècles). Journal of Juristic Papyrology Supplement 1. Varsovie: Raphael Taubenschlag Foundation.

Zacharias, Archim. 2003. Christ, Our Way and Our Life. A Presentation of the Theology of Archimandrite Sophrony. South Canaan: St. Tikhon's Seminary Press. 